\title{
Effect of Audit Quality on the Financial Performance of Deposit Money Banks in Nigeria
}

\author{
Muotolu, Peace Chikwemma, E. O. Nwadialor \\ Department of Accountancy, Chukwuemeka Odumegwu Ojukwu University, Igbariam Campus, Nigeria
}

\begin{abstract}
This study investigated the effect of audit quality on the financial performance of deposit money banks in Nigeria. The Ex-post Facto research design was adopted. The Judgmental sampling was adopted to selected 14 from the 22 listed Deposit Money Banks on the Nigerian Stock Exchange. The data collected from annual reports and accounts of deposit money banks were analyzed using the simple regression and correlation analyses. Findings f revealed that Audit Committee Size (ACSIZ) has a positive but insignificant effect on the financial performance of deposit money banks in Nigeria. Audit Committee Independence (ACIND) and Audit Committee Meetings (ACM) both have a negative and insignificant effect on the financial performance of quoted deposit money banks in Nigeria while Auditor's Size (BIG4A) has a positive and statistically significant effect on the financial performance of quoted banks in Nigeria. Based on this, the study recommended among others that the management of the deposit money banks in Nigeria should employ the services of one of the big audit firms and where this is not possible, go for an audit firm whose character and integrity is beyond question.
\end{abstract}

\section{INTRODUCTION}

\subsection{Background to the Study}

Financial statements are prepared to give useful information in making business and economic decisions. This information is of immense advantage to the users, as it helps to assess the financial state and performance of related companies. In other to boost the quality of information disclosed in the financial reports and protect the interests of shareholders, an independent examination of the financial position of the company becomes compulsory in the case of public companies. This role is accomplished by the external auditor usually appointed as a result of the board's decision. Farouk and Hassan (2013) noted that attaining quality financial reporting is hinged on the role that the external audit plays in enhancing the quality of financial reporting of quoted companies. They stated in addition that the financial statement audit is a monitoring mechanism that helps lessen information asymmetry and defend the interests of the various stakeholders by ensuring reasonable assurance that the management's financial statements are devoid of material misstatements (Farouk \& Hassan, 2014). Okaro, Okafor, and Ofoegbu (2015) posit that quality audit boosts the credibility of financial statements. Farouk and Hassan (2014) posit that attaining quality financial reporting rests on the role that the external audit plays in enhancing the quality of financial reporting of quoted companies. It is a major part of the regulatory and supervisory infrastructure and thus a pursuit of significant public interest. Audit quality is one of the crucial issues in audit practice today. The financial statement audit is a monitoring mechanism that assists to lessen information asymmetry and guard the interests of the various stakeholders by ensuring a reasonable assurance that the management's financial statements are without material misstatements. The duty of auditors should be a major contribution to financial performance, in terms of lowering the risks of remarkable misstatements and by ensuring that the financial statements are prepared according to a laid down rules and regulations. Lower risks on misstatements boost confidence in capital markets, which in turn lessens a firm's capital (Heil, 2012; Watts \& Zimmerman, 1986).
Audit quality plays a major role in ensuring an efficient market environment; an independent quality audit boosts confidence in the credibility and integrity of financial statements which is important for well-functioning markets and improved financial performance (Farouk \& Hassan, 2014).

\subsection{Statement of the Problem}

Banks and other financial intermediaries are the hubs of the world's recent financial crises. The drop in value of their asset portfolios, together with fraudulent acts of presenting fictitious financial statements and lack of non-compliance with corporate governance principles mainly as a result of distorted credit management, were some of the core structural sources of the crises (Sanusi, 2010 and Kashif, 2008). The board in seen as the major actor responsible for the failure of corporations like Enron Corporation, Tyco International, WorldCom, Global Crossing, Arthur Anderson, Oceanic bank plc., Cadbury Plc and others. (Adeyemi \& Fagbemi, 2011; Ogbonna \& Ebimobowei, 2011). The questionable role of auditors in enhancing the quality, reliability, and credibility of financial performance has been controversial. This is because auditor's independence from their clients can be tampered with through poor regulation and supervision of the auditing practice, provision of nonaudit services to the client, auditor's personal interest in the client's business among others. As a result of the foregoing, numerous researches have been done on the relationship between audit quality and performance of firms both in developed and developing countries like Nigeria, though more research was done outside Nigeria.

Majority of the works on audit quality focused on Auditorcharacteristics as proxies for audit quality while very few focused on Audit-Committee characteristics as proxies for audit quality. Farouk and Hassan (2014), Woodland and Renolds (2003), Anderson and Verma (2012), Musa and Shehu (2014), Matoke and Omwenga (2016) and Bouaziz (2012) all focused on Auditor-characteristics proxies and observed that auditor size, auditor independence, and 
auditor expertise had a significant relationship with performance among other proxies used.

Talafat Afza and Mian Sajid Nazir (2014) and Temple, Offurum and Egbe (2016) focused on Audit-Committee characteristics proxies and observed that Audit committee independence has an insignificant relationship with firm value. Audit quality being a worrisome phenomenon, makes the present study imperative at the moment as it seeks to fill the gap by investigating the effect of audit quality on the performance of Deposit Money Banks in Nigeria using a combination of the auditor-characteristics proxies and auditcommittee proxies with a more recent data to ascertain what the true position is in Nigeria. No previous studies have done so.

\subsection{Objectives of the Study}

The aim of the study is to statistically examine the effect of audit quality on the financial performance of quoted deposit money banks in Nigeria.

The Specific objectives of the study are to:

1. Ascertain the effect audit committee size has on return on assets of quoted Nigerian deposit money banks.

2. Evaluate the extent to which audit committee independence affects return on assets of quoted Nigerian deposit money banks.

3. Determine the extent to which audit committee meeting affects return on assets of quoted Nigerian deposit money banks.

4. Examine the extent to which auditor size affects return on assets of quoted Nigerian deposit money banks.

\section{REVIEW OF RELATED LITERATURE}

\subsection{Conceptual Framework} Financial Performance

Hansen and Mowen (2005), states that firm performance is very crucial to management as it is a result which has been achieved by an individual or a group of individuals in an organization related to its authority and responsibility in achieving the goal legally, not against the law, and conforming to the moral and ethics. Performance is the function of the ability of an organization to gain and manage the resources in several different ways to develop a competitive advantage. Performance measurement is, therefore, the technique whereby an organization establishes the parameters within which programmes, investments, outputs, and acquisitions are reaching the preferred results (Hunger \& Wheelan, 1997). They further explain that performance measurement involves ongoing data collection to establish if a program is implementing activities and achieving objectives, the ongoing monitoring and reporting of program accomplishments, particularly progress toward pre-established goals

Emekekwue (2008) views return on assets (ROA) as a ratio which seeks to measure the amount of profit gotten the entire assets of the firm. It is expressed as Profit before tax Total Assets Ekwe and Duru (2012) opines that return on assets (ROA) was used as dependent variables because it is an indicator of managerial efficacy. Return on assets (ROA) is a dependent variable. It is the quotient of dividing profit after tax by total assets. Lazaridis and Trynidis (2006), Falope and Ajilore (2009), Singh and Pandy (2008) and Karaduman, Akbas, Caliskan and Durers (2011) agrees that the formula for return on Assets (ROA) is expressed as Profit before tax over Total Assets.

\section{Audit Quality}

There is really no universally approved definition of audit quality (AQ). The closest and most extensively used definition is that of DeAngelo (1981). Audit quality, according to DeAngelo (1981) cited in Okaro, Okafor \& Ofoegbu (2015), "is market-assessed joint probability that a given auditor will both (a) discover a breach in the client accounting system and (b) report the breach, meaning that the auditor has both the technical competence to detect any material errors during the audit process, and the independence to guarantee that material errors and omissions are corrected or disclosed in the auditor's report. Jackson, Moldrich, and Roebuck (2008) viewed the quality of audits from actual and perceived quality. Actual quality shows levels of risk of material errors in financial statements that can be reduced by the auditor. Perceived quality indicates the level of confidence of users in financial statement and the auditor's effectiveness in reducing material misstatement in financial statements prepared by management. Titman and Trueman (1986) perceive audit quality as the correctness of the information reported by auditors.

DeAngelo definition captures attribute critically to the role played by auditors in financial statement preparation. Thus, audit quality combines the ability of an auditor to detect a breach (auditor competence) and a readiness to report such a breach (auditor independence). The Financial Reporting Council (2006b) reflects on five factors that influence audit quality and they are audit firm culture, skills and personal qualities of audit partners and staff, the effectiveness of the audit process, and the reliability and usefulness of audit reporting, amongst factor that is exogenous to the auditors.

Audit quality plays a crucial role in sustaining an efficient market environment; an independent quality audit strengthens confidence in the credibility and integrity of financial statements which is vital for well-functioning markets and improved financial performance (Farouk \& Hassan, 2014). Consequently, larger firms are able to conduct their audits to a higher standard than smaller firms. Thus audit quality (AQ) is dichotomous in nature and the size of audit firm (Big four or non-Big four) will be used as a proxy for audit quality (Ejeagbasi, et al, 2015). Further, this variable equals 1 if the external auditor of a deposit money bank in Nigeria is among the Big Four (Deloitte, Ernst and Young, Price Water Coopers and KPMG) and 0 if otherwise.

\section{Audit Committee}

An audit committee is one of the key operating committees of a company's board of directors that is in charge of overseeing financial reporting and disclosure. All U.S. publicly-traded companies must sustain a qualified audit committee so as to be listed on a stock exchange. Audit committees maintain communication with the company's chief financial officer (CFO).

The committee also has the authority to instigate special investigations in cases where it is resolute that accounting practices are problematic or when serious issues arise with employees. Besides, in the case of a public limited company (Plc), apart from the auditors' report, an audit committee comprising of an equal number of directors and 
representatives of shareholders (subject to a maximum of six) shall scrutinize the auditors' report and make recommendations to the AGM as it deems fit.

\subsection{Theoretical Framework}

This study is anchored on the Agency theory. Agency theory has been broadly used in literature to investigate the information asymmetry between principals (shareholders) and agent (management). This study uses the agency theory to establish the impact of audit quality on the financial performance of listed state corporations on the Nigerian Stock Exchange. Sarens and Abdolmohammadi (2007), states that according to the agency theory, a company is made up of a set of linked contracts between the owners of economic resources (the principals) and managers (the agents) who are entrusted with using and controlling these resources. Jensen and Meckling (1976), states that in agency theory, agents have more information than principals and this information asymmetry negatively affect the principals' ability to monitor whether or not their interests are being properly covered by the agents. Jensen and Meckling (1976) opine that moral hazard forms a situation where to maximize their own wealth, agents may face the dilemma of acting against the interests of their principals.

Since principals are not equipped with all available information at the time a decision is being made by an agent, they are not capable to determine whether the agent's actions are in the best interest of the firm. To reduce the possibility of the moral hazard, principals and agents engage in contracting to achieve optimality, including the institution of monitoring processes such as auditing. The principalagent relationship as shown in agency theory is vital to understanding how the role of an auditor has developed. Principals appoint agents and assign some decision making authority to them. In so doing, the principals place their trust in their agents to act in the principals' best interests However, because of information asymmetries between principals and agents differing motives, principals may lack trust in their agents and may, therefore, need to put in place mechanisms, such as the audit, to strengthen this trust. Agency theory, therefore, is a useful economic theory of accountability, which helps to elucidate the development of audit quality.

\subsection{Review of Empirical Studies}

Farouk and Hassan (2014) examined the impact of audit quality on the financial performance of quoted firms in Nigeria. Multiple regression analysis was employed in analyzing the data and testing the hypotheses. The results of the findings show that auditor size and auditor independence have significant impacts on the financial performance of quoted cement firms in Nigeria.

However, auditor independence has more influence than auditor size on financial performance. Ziaee (2014) investigated the relationship between audit quality and financial performance of companies in Iran. The period covered is 2008 to 2012 . Using primary data, he found that audit quality could affect the financial performance of companies. Yassin and Nelson (2012) made use of audit fee as a proxy for audit quality. They proposed that a higher audit fees show that auditors provide more efficient audit services to the companies compared to lower audit fees. Moutinho (2012) investigated the relationship between audit fees and firm performance. Using a sample of U.S. publicly traded, non-financial firms covering the period from 2000 to 2008, a fixed effects model is shown to estimate firm operating performance. The model comprised of standard control variables, such as size, leverage, sales growth, and research and development intensity. In addition, measures of corporate governance were initiated.

Specifically, increases (decreases) in operating performance are connected with decreases (increases) in audit fees. Okoye, Okaro, and Okafor (2015) studied corporate governance factors that affect audit quality, some of which if dealt with, would aid in curtailing audit failures. Using secondary data extracted from the annual reports of a sample of 104 companies randomly selected from a population of 134 non-bank companies listed in the Nigerian Stock Exchange, they came to a conclusion that small board size and greater board diligence impacted positively on audit quality. Yuniarti (2011) investigated the relationship between factors that affect audit quality of 24 Bandung firm at 2009. He suggested that higher audit fees raised and enhanced audit quality due to auditors' effort and accounting firm should enhance the number of audit fees that lead to higher audit quality. He also found that audit fees are significantly and positively affect audit quality. Hoitash, Markelevich, \& Barragato (2007) examined the relationship between audit fees and audit quality. Their paper showed that fees paid to auditor can impact in a way; large fees paid to auditor increases the quality of the audit. Higher audit fees are related to non-audit service and this makes auditors more reliant on their clients. In their study, they examined audit fees for the period from 2000 to 2003 and found that there is a significant positive relationship between audit fees and audit quality.

Modugu, Erahbhe, and Ikhatua (2012) examine the relationship between audit delay and company characteristics in Nigeria. A sample of 20 quoted companies was selected for a period of 2009 to 2011 Ordinary Least Square technique was adopted in the analysis. The result shows that multi-nationality connections of companies, company size, and audit fees paid to auditors are the major determinants of audit delay in Nigeria. The study also revealed that audit report lag for each of the companies takes a minimum of 30 days and a maximum of 276 days for Nigerian companies to publish their annual reports. Nigeria listed companies take approximately two months on the average beyond their balance sheet date before they are finally ready for the presentation of the audited accounts to the shareholders at the annual general meetings.

Fagbemi and Uadiale (2011) studied a sample of forty-five audited financial statements of quoted companies. The data collected were analyzed using descriptive and inferential statistics. Findings show that the average number of days for which financial reports are ready after the year-end is one hundred and forty-one days.

The earliest time for which audit report is made ready after year-end is thirty-one days afterward. The result indicates a relationship between corporate reporting timeliness and company affiliation with a foreign entity. However, the results found no correlation between timeliness of financial statements, business complexity, and business leverage.

Iyoha (2012) examined the impact of company attributes on the timeliness of financial reports in Nigeria. A sample of 61 
companies' annual reports for ten (10) years was selected. The data were analyzed and results estimated using Ordinary Least Square (OLS) Regression. The findings reveal that the age of the company is the major company characteristic that influences the overall quality of timeliness of financial reports.

The study also observed a significant difference in the timeliness of financial reporting among industrial sectors. For instance, the banking sector was found to be timelier in financial reporting than other sectors. Egbunike and Abiahu (2017) examined the effect of audit firm characteristics on the financial performance of money deposit banks in Nigeria.

Specifically, the study examined the effect of audit quality, audit fee, and audit report lag on return on assets of Nigerian banks. They also ascertained the effect of audit quality, audit fee, and audit report lag on earnings per share of Nigerian banks. They finally, examined the effect of audit quality, audit fee, and audit report lag on the net profit margin of Nigerian banks. The study adopted the ex-post facto and correlational research design. The study's population comprised of all money deposit banks in existence as at 2015 financial year end. The study found that audit quality has a significant effect on return on assets of Nigerian banks; Audit fee and audit report lag had no significant effect on return on assets, earnings per share and net profit margin of Nigerian banks.

In Korea, the study by Lee and Jang (2008) found that audit report lag is negatively related with non-audit fees paid to incumbent auditors. It was also seen that ARL is negatively associated with the use of Big 4 auditors and unqualified audit opinions. The study, however, did not find a significant relationship between Audit Report Lag and auditor tenure. Oladipupo (2011) investigated the extent of audit lag in Nigeria.

Forty companies were selected. Both univariate and multivariate analyses were performed on the data collected. The study observed that; audit delay ranged from 16 to 284 days; Nigeria listed companies take approximately four months on the average beyond their balance sheet date before they are finally ready for the presentation of the audited accounts to the shareholders; That profitability, total assets, total debt, total equity, audit fees, and industry type have no significant impact on audit delay. Ettredge et.al, (2008), investigated client choice of industry auditors from among the Big 4 or 5 in an international setting. They examined client-specific industry level and country-level factors. They discovered that international choice of homebased Big 4 or 5 specialist auditors is positively associated with audit quality, capital intensity and membership in a regulated industry.

Bouaziz (2012), examined the relationship between auditor size and financial performance with a sample of 26 Tunisian firms listed on the Tunis Stock Exchange. The result revealed that auditor size has a significant impact on the financial performance of firms in terms of return on assets and return on equity. Miettinen (2011), examined the relationship between audit quality and financial performance. Audit quality was evaluated using the auditor size and audit committee meeting frequency. The result shows that audit quality has both a direct effect as well as a mediated effect through audit size on financial performance. The results imply that measures of audit quality are not only symbolic but that they contribute to financial performance.

Anderson and Verma (2012), examined the relationship between auditor size, auditor tenure and audit firm rotation using a probit model which they developed. The data they collected from 2,148 listed Asian companies shows that big audit firms give high-quality audit because big audit firms are more conventional than non-big audit firms. They also discovered that national level factors have a strong influence on audit quality.

Zureigat (2010) examined the effect of financial structure among Jordanian listed firms on audit quality. Using a sample of 198 companies, his analysis of logistic regression shows a significant positive relationship between audit quality and financial structure. Nam (2011), studied the relationship between audit fees as a proxy for auditor independence and audit quality of firms in New Zealand.

Employing three multiple regression models for a sample of New Zealand companies, his study discovered that the provision of non-audit services by the auditors of a firm comprises the auditor's independence, abnormal audit fee change rate is negatively associated with audit quality and auditor's independence of the previous year impacts on the audit fee that is negotiated in the current year.

Musa and Shehu (2014) examine the impact of audit quality on the financial performance of quoted firms in Nigeria. The study is descriptive in nature and the correlational and expost facto designs were used in conducting this research. Data were obtained mainly from the published annual reports and accounts, and notes to the financial statements of the four firms that represent the sample of the study. The data collected were quantified and presented in tables. Multiple regression analysis using the SPSS Version 15.0 was employed in analyzing the data and testing the stated hypotheses. The results of the findings show that auditor size and auditor independence have significant impacts on the financial performance of quoted cement firms in Nigeria. However, auditor independence has more influence than auditor size on financial performance.

Temple, Ofurum, and Egbe (2016) studied the influence of audit committee characteristics on the quality of financial reporting in listed Nigerian banks. The study used information from the financial statements of fifteen twelvemonthly reports and accounts of the banks whose stocks are traded in the Nigerian Stock Exchange as of December 31, 2014. The research design used in the study is correlation research design. The investigator adopted Jones (1991) modified model which gave the measure for earnings management which is the representation for the quality of financial reporting. The test of hypotheses and another breakdown of data were computed by SPSS statistic 22.0. The outcomes of the study showed that the audit committee "independence has no significant effect on earnings management in quoted Nigerian banks.

Matoke and Omwenga (2016) studied the relationship between audit quality and financial performance of listed companies in Nairobi Securities Exchange. The specific objectives were: to examine the influence of size of the audit firm on the financial performance of listed companies in NSE, to determine the effect of auditors' independence on the 
financial performance of listed companies in NSE, to establish the effect of characteristics of the audit team on the financial performance of listed companies in NSE and to show how the auditor's experience influences financial performance of listed companies in NSE. This study used a descriptive research design. The sampling frame of this study was drawn from directories of the Nairobi Securities Exchange Limited; comprising of all the 9 listed companies in Kenya. Data from the ICPAK show that there are a total of 826 CPAs working in the 9 listed companies in Kenya. Simple random sampling was used to select 89 respondents since the study population was homogenous. Both primary and secondary data were used. Piloting was done to test the validity and reliability of the instruments. After inspection, the data were coded and analyzed by the use of descriptive statistics using SPSS. Data were analyzed by multiple linear regression analysis. Findings of the study showed that the effect of audit quality on financial performance is positive and significant and the more the degree of an auditors' independence, the more the tendency of a firm making substantial net profit margins. The impact of auditor size was also positive and significant, although, its impact was less than that of auditor independence.

Hamed, Rohaida, Siti Zaleha, and Mohamed (2016) examine the impact of audit quality on firm performance for Malaysian listed companies covering the period from 2003 to 2012. The study used audit fees and audit firm rotation as proxies for audit quality. Return on assets and Tobin's q are used as measures for firm performance. They found that there is an insignificant relationship between audit quality proxies (audit fees and audit firm rotation) and ROA. They also found that an audit fee is significantly and positively related to Tobin's Q. However, audit firm rotation is insignificantly related to Tobin's Q. Chen (2003) studied the relationship between Risk Based Internal Audit and corporate governance structures. It was observed that there existed a significant positive relationship between the level of RBIA used and corporate governance bank's board size. The findings of this study showed a significant negative correlation existed indicating that a small board size seems to be more effective, and is more likely to use RBIA, as a corresponding mechanism. Krishnan, (2005) on the contrary conducted an empirical analysis on the role of risk-based audit on internal corporate governance and discovered that the percentage of non-executive directors and supervisors on the board of directors was significant negative associated with the use of RBIA indicating that the higher level of independent directors and supervisors on the board gave better corporate governance, hence may not employ higher percentage of RBIA for monitoring of risk management.

Okibo and Kamau (2011) explored on the internal auditors' compliance with Quality Assurance Standards: A case of state-owned corporations in Kenya and observed that there is usually low compliance with quality assurance standards among most internal audit units in state-owned corporations in Kenya. The research recognized some of the reasons that led to low compliance to include; lack of awareness of standards; non-membership with IIA; non-adoption of IPPF; age and experience of the internal audit department and understanding of the quality assurance standards.

In 2003, Woodland and Reynolds investigated the relationship between indirect measures of audit quality and financial statement analysis using multivariate regression analysis. They found that audit fee is positively related to the financial statements but no proof was shown that auditor size, tenure or industry specialization are related to audit quality in the directions predicted. Their results gave a new evidence as to the current use of these indirect measures in predicting audit quality.

Abu Bakar et al., (2005) did a survey among 116 loan officers in Malaysia. The results revealed that 75.60 percent of the respondents indicated that the size of the audit firm did affect the auditor independence and 74.40 percent of them stated that the level of competition in the audit service market influenced the auditor independence. Furthermore, the results showed that the provision of MAS had a negative effect on the auditor independence in Malaysia. Zureigat (2010) investigated the effect of financial structure among Jordanian listed firms on audit quality. Using a sample of 198 companies, his analysis of logistic regression shows a significant positive relationship between audit quality and financial structure.

Nam (2011), observed the relationship between audit fees as a proxy for auditor independence and audit quality of firms in New Zealand. Employing three multiple regression models for a sample of New Zealand companies, his study discovered that the provision of non-audit services by the auditors of a firm comprises the auditor's independence, abnormal audit fee change rate is inversely related to audit quality and auditor's independence of the prior year impacts on the audit fee that is negotiated in the current year.

Abu, Okpeh, and Okpe (2016) examined the influence of Board Characteristics on the Financial Performance of listed deposit money banks in Nigeria for the period of 2005-2014. The total number of listed deposit money banks as at 31st December 2014 are seventeen (17) and a sample of fifteen (15) were used for the research. They investigated whether board characteristics (proxy by the executive director, an independent director, grey director, women director, and foreign director) has any influence on the Performance of listed Deposit Money Banks in Nigeria. The study used multiple regression technique as a tool of analysis and data were collected from the secondary source through the annual reports and accounts of the sampled banks. The result shows that the foreign director is significantly and positively related to the Performance of deposit money banks in Nigeria. Other variables such as executive director, independent non-executive director, and women director have no significant impact on banks performance in Nigeria.

Bogale (2016) studied the determinants of external audit quality proxied by discretionary (abnormal) accrual based on audit firm-specific and company related attributes that are considered vital by regulatory and professional bodies to properly monitor the external audit profession and to maintain trust among the various stakeholders in Ethiopian manufacturing share companies. Based on the objective, the study used a quantitative method of research approach to testing a series of the research hypothesis. Particularly, the study used a documentary analysis of companies' audited financial statements and personal inquiry with audit directors/officials of audit firms and company managers. Then companies were chosen based on simple random sampling method to avoid biases and represent firms within manufacturing share companies under consideration. Consequently, the study selected a sample of eighteen (18) 
companies for a period of five years (2011-2015) with a total of 90 observations. The results of panel least square regression analysis show that certified audit professionals' and joint provision of audit and non-audit services have statistically significant and positive relationship with manufacturing share companies' external audit quality. Conversely, the size of independent non-executive board members and the duality of chief executive officers has a negative and statistically significant relationship with large manufacturing shares' external audit quality.

Hassan (2015) examines the factors affecting the level of external audit fees paid by firms to their auditors in Jordan. Specific interest is concentrated on the examination of the potential effect of audited size, complexity of client, profitability, client risk, auditor size and auditor tenure on audit fees, by using the Sample which contains 117 nonfinancial Jordanian companies which listed on Amman Stock Exchange, meet the selection standards and have the applicable and appropriate financial data from 2010 until 2012 (351 observation). Moreover, the present study gives further evidence connecting variables such as the auditor tenure effects and auditee risk which have been found to have an inconclusive relationship with the number of external audit fees in prior studies. Moreover, financial risk is found to be negatively and significantly associated with the level of external audit fees. On the other side, empirical results found that audit tenure has no significant relationship with audit fees.

Yi-Fang, Lee-Wen, and Min-Ning (2015) investigate the comparative importance between service quality and firm size in the performance determinants of audit firms under different market segments and business strategies. This study extorts a human capital-based service quality by the principal component analysis technique.

In terms of market segment, total samples are divided into national, regional, and local audit firms. In addition, based on the business strategies audit firms take, regional and local firms are broken into two categories: stability and expansion type firms. Empirical results show that service quality is a more important performance determinant than firm size in the national firms. Next, operating performance of expanding regional firms is better than that of stability regional firms.

\subsection{Summary of the Literature Review}

The above scholars attempted to study audit quality and the factors that affect audit quality both in Nigeria and outside Nigeria. Some researchers like Farouk and Hassan (2014) and Musa and Shehu (2014) based their research on auditor characteristics while Talt Afaze (2014) and Temple et al (2016) focused on audit committee characteristics. Iyoha (2012) and Moduru et al (2012) focused on company/firm characteristics. Some researchers like Yuriart (2011) and Hortalsh (2007) dissected one factor only. Most studies abroad used primary data while few studies in Nigeria used secondary data. Some researchers use one variable, some two or three variable at most. Audit quality is really vast depending on direction the researcher wants to focus on. Studies on Audit quality would continue to come because it is a very crucial concept as long as accounting continues to exist. This study used four variables which is made up of a combination of auditor characteristic factors and audit committee characteristic factors covering a period between 2007 and 2016, using a more recent data

\section{METHODOLOGY}

The ex-post facto research design was adopted involving data obtained from the annual reports and audited accounts of the banks under assessment from 2007 to 2016.This study makes use of deposit money banks quoted on the Nigerian Stock Exchange. The study covered a period ten years and the data was gotten from the annual reports and accounts of these companies from 2007 to 2016. The banks are Access bank plc, Diamond bank plc, First bank plc, FCMB Plc, GTB plc, Zenith bank plc, Sterling bank plc, UBA Plc, Fidelity bank plc, Wema bank plc, Unity bank plc, Union bank plc, Skye bank plc and Stanbic IBTC. Of the 22 deposit money, banks listed on the Nigerian stock exchange judgmental sampling was used in selecting 14 banks representing those that did not lose their identity to the consolidation exercise.

The study used audit committee size, audit committee independence, Audit Committee meetings and Auditor size as independent variables (to proxy audit quality) and return on asset was used as the dependent variable (to proxy performance. The independent variable is audit quality (AQ).

Audit Committee Size (ACSIZ) = proxy using the number of members in the audit committee. It consists of people chosen from among the board of directors whose responsibility is to ensure that auditors' independence is kept. Audit Committee Independence (ACIND) = proxy using the proportion of nondirectors on the board

Audit Committee Meetings (AUDCM) = proxy using the number of the meeting held by the audit commit yearly. Auditor Size (AUDSIZ) = proxy using the Big Four (1)/ NonBig Four (0) dichotomy. Audit quality was set equal to one (1) if the information obtained from banks audited reports show that it is audited by one of the "big 4" audit firms (Price-water house coopers; Akintola Williams Deloitte; KPMG Professional service and Ernst and Young, otherwise zero $(0)$.

This operationalization follows the approach used in Kane and Velury (2011) where big audit firms are assumed to have quality audit services than other smaller audit firms. The financial performance as the dependent variables was proxy by return on Asset (ROA).

The conceived model was tested with the use of logistic regression. This was used to examine the relationship between dependent and independent variables. The logistic regression for this study takes the form:

$$
\begin{gathered}
\mathrm{ROA}=\beta 0+\beta 1 \mathrm{AUDCSIZ}+\beta 2 \mathrm{ACIND}+\beta 3 \mathrm{AUDCM}+\beta 4 \\
\text { AUDSIZE } \varepsilon \ldots \ldots \ldots \ldots . . \mathrm{i}
\end{gathered}
$$

Where:

ROA = Return on Asset; AUDCSIZ = Audit Committee size; ACIND=Audit committee independence; $A U D C M=$ Audit Committee Meetings; AUDSIZ= Auditor size This model was adopted by authors such as Poit and Janin (2007) and Jaikengkit (2009). 


\section{DATA PRESENTATION AND ANALYSIS}

\subsection{Data Presentation}

Table 1: Descriptive Statistics of our Variables

\begin{tabular}{llllll} 
& \multicolumn{1}{c}{ ROA2 } & ACSIZ & ACIND & ACM & BIG4A \\
Mean & 1.345455 & 6.045455 & 49.99662 & 4.207792 & 0.779221 \\
Median & 1.555000 & 6.000000 & 50.00000 & 4.000000 & 1.000000 \\
Maximum & 9.540000 & 9.000000 & 100.0000 & 7.000000 & 1.000000 \\
Minimum & -20.23000 & 4.000000 & 33.33000 & 1.000000 & 0.000000 \\
Std. Dev. & 2.760189 & 0.417601 & 4.835714 & 0.853101 & 0.416125 \\
Skewness & -3.443456 & 3.002586 & 6.780288 & 0.287322 & -1.346382 \\
Kurtosis & 27.46944 & 27.81950 & 77.63185 & 6.337552 & 2.812745 \\
Jarque-Bera & 4146.342 & 4184.113 & 36920.23 & 73.59576 & 46.75212 \\
Probability & $0.000000^{*}$ & $0.000000 *$ & $0.000000 *$ & $0.000000 *$ & $0.000000 *$ \\
Sum & 207.2000 & 931.0000 & 7699.480 & 648.0000 & 120.0000 \\
Sum Sq. Dev. & 1165.653 & 26.68182 & 3577.772 & 111.3506 & 26.49351 \\
Observations & 154 & 154 & 154 & 154 & 154
\end{tabular}

Source: Researcher's computation (2018): Note *1\% level of significance, **5\% level of significance, ***10\% level of significance.

Table 1 shows the mean (average) for each of the variables, their maximum values, minimum values, standard deviation and Jarque-Bera (JB) statistics (normality test). The result in Table 1 provided some insight into the nature of the selected variables used in this study. First, the table shows that all the quoted deposit money banks used for this study have positive financial performance, proxy as Return on Assets (ROA). The table shows that on the average, the mean value of 1.35 for ROA means that during the period of the study, all the fourteen (14) quoted banks used for this study recorded a positive financial performance. We also observed a maximum value of 122.80, 9.54, 9.00, 100.00, 7.00 and 1.00 for our independent variables of Audit Committee size(ACSIZ), Audit Committee Independence(ACIND),Audit Committee Meetings(ACM) and Auditor Size(BIG4A) respectively while their minimum values stood at $-394.32,-20.23,4.00,33.33,1.00$, and 0.00 respectively. These values, therefore, show a wide variation in their maximum and minimum values. These wide variations in our explanatory variables maximum and minimum values therefore justifies the need for this study as we expect that deposit money banks with greater number in their audit committee size(ACSIZ), higher Audit Committee independence(ACIND), higher number of Audit Committee Meetings (ACM) recorded as well as being audited by any of the Big Four(4) Auditing firms(BIG4A) will financially perform better than those banks that do not. Similarly, the table also shows a standard deviation of our explanatory variables $0.42,4.84,0.85$ and 0.41 respectively, which are widely dispersed. This means that the quoted deposit money banks used for this study are well dispersed, not dominated by either large or small banks.

Lastly, in Table 1, the Jarque-Bera (JB) which test for normality or the existence of outlier or extreme values among the variables shows that all our variables are normally distributed at $1 \%$ level of significance. This also implies that the least square regression can be used to estimate the pooled regression models. The Kurtosis and skewness of our variables also show that the variables used in this study were normally distributed.

\subsection{Normality Testing}

To further check for the normality of our variables, a Jarque-Bera normality test was further carried out and the result is presented as a graph in figure 1 below.

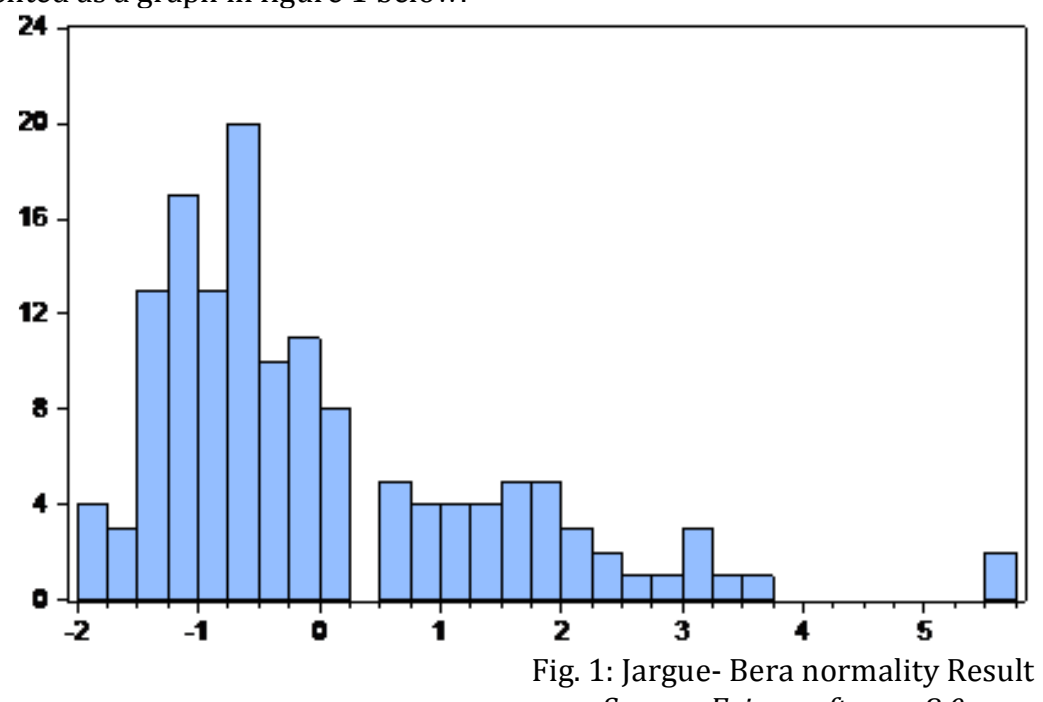

$\begin{array}{ll}\text { Series: Standardized Residuals } \\ \text { Sample 2011 } 2017 \\ \text { Observations } & 140 \\ & \\ \text { Mean } & -1.43 \mathrm{e}-16 \\ \text { Median } & -0.501225 \\ \text { Maximum } & 5.559035 \\ \text { Minimum } & -1.996361 \\ \text { Std. Dev. } & 1.446289 \\ \text { Skewness } & 1.374492 \\ \text { Kurtosis } & 4.970923 \\ & \\ \text { Jarque-Bera } & 66.74179 \\ \text { Probability } & 0.000000\end{array}$

Source: Eview software 8.0

The graph result above shows that the variables used for this study, with the J argue-Bera value of 66.74179 and probability value of 0.00 , are normally distributed at $1 \%$ level of significance and therefore fit to be used for this study. 


\subsection{Correlation Analysis}

In examining the association between the variables, we employed the Pearson correlation coefficient (correlation matrix) and the results are presented in Table 2.

\begin{tabular}{lccccc}
\multicolumn{7}{c}{ Table 2: Pearson Correlation Matrix } \\
& ROA & ACSIZ & ACIND & ACM & BIG4A \\
\hline ROA & 1.00 & 0.13 & 0.07 & 0.02 & 0.21 \\
ACSIZ & 0.13 & 1.00 & 0.40 & 0.01 & 0.02 \\
ACIND & 0.07 & 0.40 & 1.00 & 0.02 & 0.00 \\
ACM & 0.02 & 0.01 & 0.02 & 1.00 & 0.11 \\
BIG4A & 0.21 & 0.02 & 0.00 & 0.11 & 1.00 \\
\hline
\end{tabular}

Source: Researcher's computation (2018)

The use of a correlation matrix in most regression analysis is to check for multicollinearity and to explore the association between each explanatory variables and the dependent variable. Table 2 focuses on the correlation between our dependent variable (Financial performance proxy as ROA) and the independent variables which include ACSIZ, ACIND, $\mathrm{ACM}$ and BIG4A. The findings from the correlation matrix table shows that all our explanatory variables were positively and weakly correlated with our dependent variable, $\quad$ ROA/ACSIZ=0.13: $\quad$ ROA/ACIND=0.07: $\mathrm{ROA} / \mathrm{ACM}=0.02$ and $\mathrm{ROA} / \mathrm{BIG} 4 \mathrm{~A}=0.21$. In checking for multicolinearity, we notice that all our explanatory variables were not perfectly correlated. This means that there is no presence of a multicolinearity problem in our model. Multicolinearity between explanatory variables may result in wrong signs or implausible magnitudes in the estimated model coefficient, and the bias of the standard errors of the coefficients. Therefore, our estimated model is fit for regression analysis.

\subsection{Financial Performance (ROA) Model}

The ROA pooled OLS regression results examined the effect of audit quality on the financial performance of deposit money banks in Nigeria and the results obtained are presented in Table 4.

Table 4: Financial Performance (ROA) Model Regression Result



Source: Researchers computation (2018): Note: *1\%, ** 5\%, ***10\% level of significance

In testing for a cause-effect relationship between the dependent and independent variable in financial performance (ROA) model, we reported the OLS pooled regression results in Table 4 . In table 4 , we observed that from the ROA result, the R-squared and adjusted R-squared values were 0.10 and 0.07 respectively. This indicates that all the independent variables jointly explain about $10 \%$ of the systematic variations in ROA. The F-statistics values for the model stood at 2.444192 with p-value of 0.05 , showing the goodness of fit of the model, indicating that the regression model is generally significant and well specified.
In addition to the above, the specific findings from each explanatory variable from the OLS regression model are provided as follows:

Audit Committee Size (ACSIZ) and Financial Performance (ROA), based on the T-statistics value of 1.492622 and pvalue of 0.14 was found to have a positive influence on Financial Performance (ROA) but this influence is not statistically significant because its $\mathrm{p}$-values are more than 0.10 . This, therefore, suggests that we should accept our null hypothesis one (HO1) which states that Audit Committee Size (ACSIZ) has no significant effect on Return on Assets of deposit money banks in Nigeria. This means that on the basis of the use of ACSIZ to drive financial performance of quoted banks in Nigeria, Banks with a higher number of audit committee size performs better but since this performance is not statistically significant, policymakers should ignore it.

Audit Committee Independence(ACIND) and Financial Performance(ROA), based on the T-statistics value of 0.248957 and $p$-value of 0.80 was found to have a negative influence on Financial Performance (ROA) but this influence is not statistically significant because its $p$-value is more than 0.10 . This, therefore, suggests that we should accept our null hypothesis two (HO2) which states that Audit Committee Independence (ACIND) does not significantly affect the Return on Assets of deposit money banks in Nigeria. This means that on the basis of the use of ACIND to drive financial performance of quoted banks in Nigeria, Banks with less of audit committee independence performs better but since this performance is not statistically significant, policymakers should ignore it.

Audit Committee Meetings(ACM) and Financial Performance(ROA), based on the T-statistics value of 0.030097 and $p$-value of 0.98 was found to have a negative influence on Financial Performance (ROA) but this influence also is not statistically significant because its p-value is more than 0.10 . This, therefore, suggests that we should accept our null hypothesis three (HO3) which states that Audit Committee Meetings (AUSIZ) has no significant effect on Return on Assets of deposit money banks in Nigeria. This means that on the basis of the use of ACM to drive financial performance of quoted banks in Nigeria, Banks with less number of audit committee meetings performs better. This might be true since less number of ACM will result to cost reduction when compared with the higher number of ACM. But since this effect is not statistically significant, policymakers should ignore it.

Auditor's Size(BIG4A) and Financial Performance(ROA), based on the T-statistics value of 2.599627 and p-value of 0.01 was found to have a positive influence on Financial Performance (ROA) and this influence is statistically significant at $5 \%$ level of significance because its $p$-values are less than 0.05 . This, therefore, suggests that we should reject our null hypothesis four (HO4) which states that Auditor's Size proxy as BIG4A has no significant effect on Return on Assets of deposit money banks in Nigeria. This means that on the basis of the use of BIG4A to drive financial performance of quoted banks in Nigeria, Banks that are been audited by any of the four(4) big auditing firms performs significantly better than those quoted banks that are been audited by auditing firms other than the Big4 auditing firms. The implication of this result is that the quality of audit reports presented by quoted deposit money banks in Nigeria 
that are been audited by any of the Big4 auditing firms is higher and more reliable in quality than those banks that are been audited by auditing firms other than the big4 auditing firms. This reliability in their audited report, therefore, drives their financial performance higher as more customers and investors will be attracted to their services. Therefore, policymakers in other to drive audit quality among quoted deposit Money banks in Nigeria, should make policy that will ensure that quoted banks in Nigeria are been mainly audited by big4 auditing firms.

\subsection{Discussion of Results}

This study investigated the effect of audit quality on the financial performance of deposit money banks in Nigeria. Using pooled data, the data generated were subjected to different statistical tests such as descriptive statistics, correlation analysis, and Ordinary Least Square regression analysis. The descriptive statistics revealed the individual characteristics of the variables used in this study which also revealed that the variables were normally distributed.

The regression result shows that Audit Committee Size (ACSIZ) has a positive but insignificant effect on the financial performance of deposit money banks in Nigeria. This finding negates our prior expectation as we expect that ACSIZ will drive the financial performance of quoted banks in Nigeria. This our findings agree with the findings of Okoye, Okaro, and Okafor (2015) and negates the findings of Talat Afza and MianSajid Nazir (2014). Secondly, the regression results also show that Audit Committee Independence (ACIND) and Audit Committee Meetings(ACM) individually have a negative and insignificant effect on the financial performance of quoted deposit money banks in Nigeria. These findings do not support our prior expectation and also agrees with the findings of Temple, Ofurum, and Egbe (2016) and negates the findings of Afza and Nazir (2014). However, auditor Size, proxy as BIG4A has a positive and statistically significant effect on the financial performance of quoted banks in Nigeria. This finding supports our prior expectation as we expect that BIG4A will drive the financial performance of quoted banks in Nigeria. This our findings also agrees with the findings of Farouk and Hassan (2014) and negates the findings of Woodland and Reynolds (2003).

\section{CONCLUSION AND RECOMMENDATIONS}

This research work investigates the effect of audit quality on the financial performance of deposit money banks in Nigeria. The study attempted to provide empirical evidence of this effect within the Nigerian context. Findings from the study revealed that of the control variables, audit Committee Size has a positive but insignificant effect on financial performance, Audit Committee Independence and audit committee Meetings individually have a negative and insignificant effect on financial performance, while auditor's Size has a positive and statistically significant effect on the financial performance.

Based on the findings of the study, the researcher recommends the followings:

1. Policymakers should not base performance on the number of audit committee size as it not statistically significant.

2. The management of deposit money banks in Nigeria should not increase the number of Non-Executive Directors in the Audit Committee as having more of the non-executive directors on the board has not been proven to be statistically significant.

3. The number of audit committee meetings does not really matter as it has not been statistically proven that less number of meetings reduce cost.

4. The management of the deposit money banks in Nigeria should employ the services of one of the big audit firms and where this is not possible, management should go for an audit firm whose character and integrity is beyond question; hence the debate on audit quality is not a settled

\section{REFERENCES}

[1] Abbott, L., Parker, S. \& Peters, G. (2004). Audit committee characteristics and restatements, Auditing: A Journal of Practice \& Theory 23, 69-87.

[2] Abu, S. O., Okpeh, A. J. \& Okpe, U.J. (2016). Board characteristics and financial performance of deposit money banks in Nigeria. International Journal of Business and Social Science 7(9); September 2016159

[3] Afza, T. \& Nasir, M.S. (2014) Audit Quality and Firm Value: A Case of Pakistan. Research Journal of Applied Sciences, Engineering and Technology 7(9): 18031810,ISSN: 2040-7459; e-ISSN: 2040-7467

[4] Ahmed, A.A., \& Hossain, M.S. (2010). Audit report lag: a study of the Bangladeshi Listed Companies. ASA UniversityReview, 4(4), 49 - 56.

[5] Aronmwan, E.J., Ashafoke, T.0. \& Mgbame, C.O. (2013). Audit Firm Reputation and Audit Quality. Electronic copy available at: http://ssrn.com/abstract $=2642722$

[6] Bédard, J., Chtourou, S. \& Courteau, L. (2004). The effect of audit committee expertise, independence, and activity on aggressive earnings management, Auditing: A Journal of Practice \& Theory, 23(2), 13-35.

[7] Bell, T.B., R., Doogar \& Solomon, I. (2008). Audit labour usage and fees under business risk auditing", Journal ofAccounting Research, 46(4) pp.729-760.

[8] Bouaziz, Z. (2012). The impact of auditor size on financial performance of Tunisian companies. Paper presented at the Faculty of Economics and Management. Sfax University, Tunisia.

[9] Carcello, J. V., \& Nagy, A. L. (2004). Audit firm tenure and fraudulent financial reporting. Auditing: A Journal of Practice and Theory, 23(2), 55-69.

[10] Dogan, M., Coskun, E. \& Celik, O. (2007). Is timing of financial reporting related to firm performance? - an examination on ISE Listed Companies. International Research Journal of Finance and Economics, Vol. 12, pp.220-233.

[11] DeZoort, F. T., Herman son, D.R., Archambeault, D.S. \& Reed, S.A., (2002). Audit committee effectiveness: a synthesis of the empirical audit committee literature", Journal of Accounting Literature, Vol. 21, p. 38-75, 2002.

[12] De Angelo, L. (1981). Auditor size and audit quality. Journal of accounting and economics, 2 (1).

[13] DeZoort, F.T. \& Salteerio, S.E. (2001). The effects of corporate governance experience and financial reporting and audit knowledge on audit committee members judgment." auditing: A Journal of Practice and Theory. 20 (2): $31-47$.

[14] Egbunike, F. C. \& Abiahu, M.C.( 2017) Audit Firm Report and Financial Performance of Money Deposit Banks in Nigeria 
[15] Emekekwue, P.E. (2008). Corporate financial management. 5th Revised ed; Kinshasha: African Bureau of Educational Sciences.

[16] Ekwe, M. C. \& Duru, A.N. (2012). Liquidity management and corporate profitability in Nigeria ESUT. Journal of Accountancy 3(1): 22 - 28.

[17] Ejeagbasi, G E., Nweze, A.U; Ezeh, E.C. \& Nze, D. O. (2015). Corporate governance and audit quality in Nigeria: evidence from the banking industry. European Journal of Accounting, Auditing and Finance Research5 (1).

[18] Ettredge, M., J. Heintz, C. Li, \& S. Scholz. "Auditor realignments accompanying implementation of SOX 404 reporting requirements". Working paper, University of Kansas. 2008.

[19] Farouk, M. A. \& Hassan, S., U. (2014).Impact of Audit Quality and Financial Performance of Quoted Cement Firms in Nigeria International Journal of Accounting and Taxation. June 2014, Vol. 2, No. 2, pp. 01-22

[20] FRC (2006), Promoting Audit Quality, Discussion Paper, London: Financial Reporting Council.

[21] Falope, O. \& Ajilore, 0.T. (2009). Working capital management and corporate profitability: Evidence from panel data analysis of selected quoted firms in Nigeria Research Journal of Business Management 3(3): $73-84$.

[22] Hamed, S., Rohaida B., Siti, Z. A. R. \& Mohamed, A. E. (2014). The Impact of Audit Quality on Firm Performance: Evidence from Malasia. International Business School, Universiti Teknologi Malaysia, Kuala Iumpur, Malaysia

[23] Heil, D. (2012). The influence of the auditor on the earnings quality of their clients. (Umpublished Masters Thesis). Department of Accounting, Auditing and Control, Erasmus University, Rotterdam.

[24] Jackson, A. B., Moldrich, M., \& Roebuck, J. K. (2008). Audit-firm tenure and the quality of financial reports. Contemporary Accounting Research, 19 (4), 637 - 660.

[25] Jensen, M.C. \& Meckling, (1976). Fama \& Jensen, 1983; Jensen, (1993). Theory of the Firm: Managerial Behavior, Agency Costs and Ownership Structure. Journal of financial economics, October, 1976, 3(4) pp. 305-360.

[26] Lazaridis, I \& Tryfonidis, D (2006). Relationship between working capital management and profitability of listed companies in the Athens Stock Exchange Journal of Financial Management and Analysis 19(5): 26 -35 .

[27] Karaduman, H. A ; Akbas, H. E; Caliskan, A. O \& Durers (2011). The relationship between working capital management and profitability: Evidence from an emerging market International Research Journal of Finance and Economics 62: 61 - 67.

[28] Matoke V. N. \& Omwenga, J. (2016). Audit Quality and Financial Performance of Companies Listed in Nairobi Securities Exchange International Journal of Scientific and Research Publications, Volume 6, Issue 11, November 2016372 ISSN 2250-3153 www.ijsrp.org

[29] Menon, K., \& Williams, J.D., (1994). The use of audit committees for monitoring. Journal of Accounting and Public Policy 13 (2), 121 - 139.
[30] Miettinen, J. (2011). The role of audit quality on the relationship between auditee's agency problems and financial information quality. Paper presented at the Department of Accounting and Finance University of Vaasa, Finland.

[31] Moutinho, V.N. (2012), Audit fees and firm performance. Dissertação do Mestrado em Finanças e Fiscalidade, FaculdadeDe Economia, Universidade Do Porto

[32] Sanusi, L. S. (2010). The Nigerian banking industry: what went wrong and the way forward" (Being the full text of a Convocation Lecture delivered at the Convocation Square, Bayero University, Kano.

[33] Stanley, J.D. (2011). Is the audit fee disclosure a leading indicator of clients' business risk?", Auditing: A Journal of Practice \& Theory, Vol. 30, No. 3, pp.157-179.

[34] Singh, J.P. \& Pandy, S. (2008). Impact of working capital management in the profitability of Hindalco industries Limited. The IUP Journal of financial Economics 6(4): 62 $-72$.

[35] Talat, A. \& Mian S.N. (2014). Audit quality and firm value: A case of Pakistan. Research Journal of Applied Sciences, Engineering and Technology 7(9):1803-1810

[36] Titman, S. \& Trueman, B. (1986). Information quality and the valuation of new issues. Journal of Accounting and Economics, 8 (2), 159 - 172.

[37] Temple, M., (2016). The impact of audit committee size on the quality of financial reporting in quoted Nigerian banks. International Journal of Advanced Academic Research / Social \& Management Sciences | ISSN: 24889849 2(5) (May 2016)

[38] Temple, M., Ofurum, C.O. \& Egbe, S. (2016). Audit committee characteristics and quality of financial reporting in quoted Nigerian banks. International Journal of Advanced Academic Research / Social \& Management SciencesISSN: 2488-9849 2(5) (May 2016)

[39] Okaro, S.C., \& Okafor, G.O. (2015), Cultural Factors and Audit Quality - Evidence from Nigeria. International Journal of Academic Research in Accounting, Finance and Management Sciences, 5(2), 17-22. doi:10.6007/IJARAFMS/v5-i2/1558

[40] Okaro, S. C., Okafor, G. O. \& Ofoegbu, G.N. (2015), The effect of joint audit on audit quality - the perceptions of accountants, auditors and accounting academics. Paper presented atthe African Accounting and Finance Association AAFA, 2015Conference at Mauritius. DOI: 10.13140/RG.2.1.2695.6009

[41] Okoye, E. I, Okaro, S. C., Okafor, G. O. (2015), Corporate Governance and Audit Quality. Paper presented at the Institute of Chartered Accountants of Nigeria First Academic Conference inLagos. Available through Research gate.

[42] Watts, R. L \& Zimmermen, J. (1986). Positive accounting theory. Engle wood Cliffs: Prentice Hall.

[43] Xie, B., Davidson, W.N. \& DaDalt, P.J. (2003). Earnings management and corporate governance: the roles of the board and the audit committee, Journal of Corporate Finance, 9, 295-316.

[44] Yang, J. \& Krishnan, J. (2005). Audit committees and quarterly earnings management, International Journal of Auditing, 9(3), 201-209. 